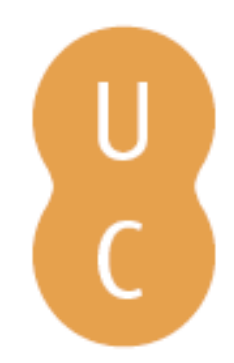

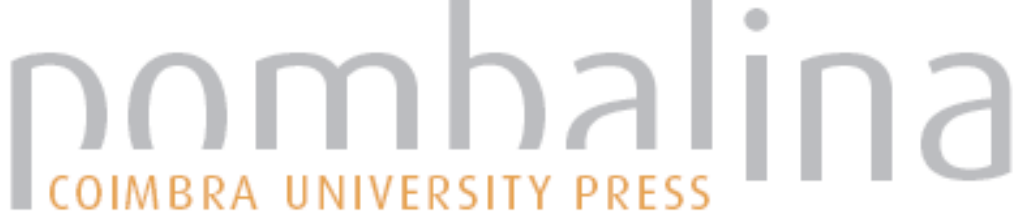

\section{History as identity: the Adriatic sea}

Autor(es): Ivetic, Egidio

Publicado por: Imprensa da Universidade de Coimbra

URL

persistente: URI:http://hdl.handle.net/10316.2/43210

DOI: $\quad$ DOl:https://doi.org/10.14195/978-989-26-1483-0_3

Accessed : $\quad$ 26-Apr-2023 16:20:53

A navegação consulta e descarregamento dos títulos inseridos nas Bibliotecas Digitais UC Digitalis, UC Pombalina e UC Impactum, pressupõem a aceitação plena e sem reservas dos Termos e Condições de Uso destas Bibliotecas Digitais, disponíveis em https://digitalis.uc.pt/pt-pt/termos.

Conforme exposto nos referidos Termos e Condições de Uso, o descarregamento de títulos de acesso restrito requer uma licença válida de autorização devendo o utilizador aceder ao(s) documento(s) a partir de um endereço de IP da instituição detentora da supramencionada licença.

Ao utilizador é apenas permitido o descarregamento para uso pessoal, pelo que o emprego do(s) título(s) descarregado(s) para outro fim, designadamente comercial, carece de autorização do respetivo autor ou editor da obra.

Na medida em que todas as obras da UC Digitalis se encontram protegidas pelo Código do Direito de Autor e Direitos Conexos e demais legislação aplicável, toda a cópia, parcial ou total, deste documento, nos casos em que é legalmente admitida, deverá conter ou fazer-se acompanhar por este aviso.

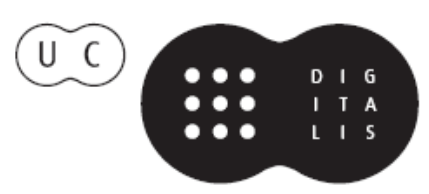




\section{IDENTITY(IES) A MULTICULTURAL AND MULTIDISCIPLINARY APPROACH}

\section{ANA PAULA ARNAUT \\ (ORG.)}

IMPRENSA DA UNIVERSIDADE DE COIMBRA

COIMBRA UNIVERSITY PRESS 
HISTORY AS IDENTITY: THE ADRIATIC SEA

Egidio Ivetic

University of Padova

\begin{abstract}
The Adriatic is a homogeneous sea as far as its form is concerned, and at the same time a complex one when its cultural stratifications are considered, stratifications particularly evident along the eastern littoral, a border zone between civilization models, between Western and Eastern Europe, Central Europe and the Mediterranean. The Adriatic as a region does not have a common historiography, there is not a single version of its past accepted by all the nations that make part of it. Recent trans-frontier policies impose a new political vision of the Adriatic, a regionalization of this sea. This tendency will have, sooner or later, a cultural implication, involving the way we look at the Adriatic past.
\end{abstract}

Keywords: The Adriatic Sea; History and Historiography; Transnational History.

The Adriatic shares a central position in the Mediterranean with Italy and it is one of the characteristic faces of Mediterranean Europe. It was the South for anyone crossing the Alps and the Latin West 
for those landing in Puglia from the Byzantine and then Ottoman Levant. The Adriatic could be a conceptual tool for a transnational approach to study and research the past of a sea. The sea has the advantage in narrational terms that it escapes the ideological straitjackets inherent in nation state categories. The Adriatic is a closed sea, a sea of passage, a frontier between East and West. It is a minor Mediterranean (Anselmi, 1991: 13-36; Cabanes, 2001: 7-26) ${ }^{34}$. A zone where multiple borders of political, cultural, religious and finally national nature have for centuries been interlaced and overlapped. The Adriatic is a homogeneous sea as far as its form is concerned, and at the same time a complex one when its cultural stratifications are considered, stratifications particularly evident along the eastern shore of the sea, a border zone between people, languages, civilization models, but also a border zone between Western and Eastern Europe, between Central Europe and the Mediterranean (Sivignon, 2001, 13-22) ${ }^{35}$.

In the Mediterranean context the Adriatic has always had a very pronounced individuality. ${ }^{36}$ From $15^{\text {th }}$ to $19^{\text {th }}$ century the Mediterranean sea was roughly considered as the whole of three maritime units-regions, divided by an imaginary line placed between Tunisia, eastern Sicily, Salento (Apulia) and the Ionian Islands: the region to the west of such line was known as the Western Mediterranean, the one to the east the Eastern Mediterranean or the Levant, and the Adriatic sea to the north of the line, the most inland

${ }^{34}$ See also: Turri, 1999; 2000; Turri, Zumiani, 2001. Meanings of the Adriatic: Matvejević, 1995; Falaschini, Graciotti, Sconocchia; Fiori, 2005; Cocco, Minardi, 2007.

35 See also: Kayser, 1996; Bosetti, 2006.

36 The Mediterranean as a historical region: Carpentier, 1998; Horden, 2000; Marino, 2002; Morris, 2003; Abulafia, 2003; Harris, 2005; Tabak, 2008; Abulafia, 2011. See also: Barbero, 2006-2010. Cultural meanings of the Mediterranean: Matvejević, 1999; Chambers, 2008; Cassano, 2011. The sea as cultural and historical topic: Peron, Rieucau, 1996; Bentley, Bridenthal, Wigen, 2007; Klein, Mackenthun, 2004; Corbin, Richard, 2004; Frascani, 2008. 
regarding Europe (Braudel, 1966: 7-145). Since the 19 ${ }^{\text {th }}$ century, this particular significance and central role of the Adriatic has been decreasing. Today the Adriatic is divided among six states: Italy, Slovenia, Croatia, Bosnia-Herzegovina, Montenegro and Albania. That number would be seven if we also count Greece, considering that northern part of the island of Corfu is bathed by the Adriatic. It is notable that the Western Mediterranean includes six states, while the Eastern Mediterranean is shared by ten states (Lacoste, 2006).

The Adriatic does not have a common historiography, there is not a single version of its past accepted by all the nations that make part of it. Instead of that there are various, sometimes conflicting, national historical visions that reflect current political situation. ${ }^{37}$ As if the national states possessed the sovereignty on the past of the Adriatic territories pertaining to them. This vision of the past is communicated under nationalistic rules of interpretation. According to such theories, the long-lasting Venetian or Ottoman domination is represented as an occupation and an economic exploitation of the populations on either side of the Adriatic that have created today's nations in the region (Novak, 1962: 39-107)38. Generally, the foreign political factor is introduced as dominating owner or landlord, a recurrent topos in the historiography of the Eastern Adriatic as is also often found in the rest of South-East Europe. The foreign dominations are those represented by the Hungarian kingdom, Venice, the Habsburg and the Ottoman empire, but also by fascist Italy. These historical entities have developed and imposed imperial systems in order to control the regions situated next to the Adriatic, the Alps and the Danube, dominating the western Balkans; such systems were almost always considered as imperialistic entities

${ }^{37}$ As examples of conflicting visions of the adriatic past, see: Cassi, 1915; Randi, 1914; Tamaro, 1918-19 ; Novak, 1932; Novak, 1962.

38 See also: Graciotti, 2001. 
judged by the $19^{\text {th }}$ century way of thinking. Needless to say how such prejudiced interpretations limit access to primary historical sources and complicate the collaboration among historiographies.

The history of the Adriatic sea therefore pays tribute to national histories. But national histories are not the only ones. The historian who wants to write a synthesis of the Adriatic history must bear in mind at least a dozen regional histories and tens of local histories of towns, islands, villages, sanctuaries ${ }^{39}$. Seen from the minimal local or regional perspective, the Adriatic appears as a protagonist, not as a background of national events. In this way one may discover ancient trade between the sea coasts, migratory flows of various population groups ${ }^{40}$.

After all, the Adriatic reveals itself as a sea-region; its history is a regional one in which we find the sum of past of the regions facing it: Apulia, Abruzzi and Molise, the Marche, Romagna, Ferrara, the Venetian lagoon, the Karst Plateau with Trieste, Istria, Dalmatia, the Croatian shoreline and the ancient Croatia, the Bay of Kotor, today's Montenegrin coast till the Drim river, the Albanian coasts and Corfu, considered the entrance key to the Adriatic. In order to encompass such plurality of histories it is necessary to start from the interpretation model elaborated by Fernand Braudel, the one that still remains unequalled (1977, 1978). The Adriatic, like all seas, is formed: (a) by a "liquid space" or "liquid plain" (Braudel's terms), in which in time we measure routes, traffic of goods, coastal trade, exploitation of the resources, fishing activities, political and military control, maritime sovereignty; (b) by the coast, or better to say within whole coastal regional systems, a sort of membrane that represents

39 See, for example: Anselmi, 1988.

40 For what concerns historical contacts between two littorals, we have a conspicous bibliography: Palumbo, 1973; Di Vittorio, 1981; Branca, Graciotti, 1983; Palumbo, 1989; Graciotti, 1992; Graciotti, Massa, Pirani, 1993; Braccesi, Graciotti, 1999; Graciotti, 2009; Bruni, Maltezou, 2011. 
the marine front when coming from inland and the terrestrial front when approaching from the sea, almost everywhere and always populated habitat, at least with minimal settlements; (c) by a wide surrounding area: as the great Mediterranean (Braudel), there also existed through the centuries a great Adriatic, in a way a crown of inland regions closely related to the sea; an extended area, having not easily detected precise borders since they could be placed some 40-50 kilometres from the coast, but could also include places like Benevento, Bologna, Padua, Lubiana, Sarajevo.

The Adriatic has its time, inside its "long durée". There are some fundamental aspects that characterize it, there are similarities and specificities compared to the rest of the Mediterranean. Like elsewhere, the urban system has been defined in the Roman age, between the 1 st century $\mathrm{BC}$ and the $5^{\text {th }}$ century $\mathrm{AD}$, with the foundation and the development of cities in Apulia and on the eastern coast, from Aquileia to Apollonia (near Valona) (Cabanes, 2001: 23-106). The disposition of these centres, their connections with islands and inlands, the formation of zones of influence, of countrysides (contadi) and then of the regions, as well as the net of roads into the continent, are all aspects that influenced the Adriatic history all the way to the present Brogiolo, Delogu, 2005).

In the $6^{\text {th }}$ century the Byzantine age begins. Byzantium had the control of the western Adriatic coast (one thinks of Ravenna and Romagna) till the 8th century, while Venice, Dalmatia and what will become the Albanian coasts made part of the Byzantine Commonwealth till the $11^{\text {th }}-12^{\text {th }}$ centuries. The territorial and maritime arch developed between Venice, Dalmatia and the Levant was in conflict with the inland where the Lombards and the Slavs had been settled. From an inner sea, the Adriatic turned into a border sea between Byzantium and the new populations. During this phase the Adriatic maritime routes strengthened along the south-east/north-west axis; the eastern Adriatic became communication link between 
Byzantium and the Ravenna exarchate and then with the Venetian (Ducellier, 2001: 107-312). Venice-Rialto became the inheritor of the Byzantine maritime system. Remnants of the Byzantine tradition are to be found in the Serb and Greek religious confession along the coastline and the inland of south-eastern Adriatic, but there also belongs the city of Venice, especially its most ancient sight (Saint Marco).

Venice imposed its authority, but not yet its sovereignty, over Dalmatia in the year 1000. The first crusades brought the Adriatic sea in the focus of communication between West and East; not only Venice-Dalmatia but also the cities of Apulia had a remarkable development from the $12^{\text {th }}$ century onwards. While the western coast of the sea with the exception of Apulia, due to technical-maritime reasons remained relatively passive to the economic and political transformations, the political role of the Ecclesiastical Church remained also marginal, but Venice developed along the oriental coast its economic, political and cultural space, in particular after the forth crusade of 1202-1204 (Ortalli, Ravegnani, Schreiner, 2006).

The control of the Eastern Adriatic was fundamental to the aims of the political and economic dominion that Venice formed in the Levant between $13^{\text {th }}$ and $15^{\text {th }}$ century (Doumerc, 2001: 201-312). Its geo-strategic dominance in the entire Adriatic became a reality with its sovereignty over Dalmatia, 1204-1358 and 1409-1707, over Istria 1267/1420-1797 and Ionian Islands, 1386-1797. The Adriatic became in effect "the Gulf of Venice" (Hocquet, 2006; Judde de Lariviere, 2008). The Venetian hegemony was nonetheless constantly questionable. The first antagonist of Venice was Hungary, between 1102 and 1409. Genoa, the rival in the Levant and in the Black Sea, did not hesitate to attack the "Most-serene" Republic in the heart of its gulf, besieging certain lagoons (Krekić, 1997: 43-65). Then came the turn of the Habsburgs between $16^{\text {th }}$ and $18^{\text {th }}$ century. Venice clashed twice with the Habsburgs, in 1508-1516 and in 1615-1618; no other wars ensued only because both rivals were threatened by the 
Ottomans. Much more complex was the relationship between Venice and the Ottomans. Venice fought seven wars against the Sublime Porte between 1469 and 1718, but in the meantime it managed to acheive long periods of peace, 1573-1645 and 1718-1797 (Ivetic, 2011: 63-72). After all, the Ottomans were less dangerous neighbours than the Habsburgs who tried on more occasions to tilt militarily and economically the Adriatic hegemony of Venice (Chaline, 2001: 313-505). On the other hand, the Ottomans had politically united the Levant under their empire, becoming a sole opponent in numerous markets. The role of the kingdom of Naples in the Adriatic context remained marginal from $16^{\text {th }}$ to $18^{\text {th }}$ century; nevertheless, the role of Apulia was that of being a commercial bridge towards the Levant. The republic of Ragusa completed the political picture, being a small Venice and, together with the Venetian Dalmatia, the interface of the West on the Balkan shores.

From $15^{\text {th }}$ to $18^{\text {th }}$ century the Adriatic became in all aspects a region where various civilizations coexisted. Apart from being a shoreline-border between Catholicism and Orthodoxy, the Eastern Adriatic became the westernmost zone where Ottoman Islam held coasts of Dalmatia and Albania, beginning from the $16^{\text {th }}$ century (Ortalli, Schmitt, 2009). Today this aspect is often underestimated. The historical continuity of Islam in the Adriatic is also underestimated. Nevertheless, the Adriatic basin, at least judging by Venetian dominions and the Italian shore, was culturally homogeneous area during the $17^{\text {th }}$ and $18^{\text {th }}$ century, especially from the point of view of literature and arts circulation ${ }^{41}$. In 1797 the Venetian Republic collapsed with the arrival of the Napoleonic troops, so the Habsburgs became for several years a dominating force in the Adriatic (Ivetic, 2011: 23-38). The French return in the years 1805-1813 brought the end of the republic of Ragusa, the creation of the kingdom of

41 See: Zorić, 1989; Branca, Graciotti, 1983; Graciotti, 1992. 
Italy and, in 1809-1813, the birth of the Illyric Provinces, a piece of metropolitan France on the Adriatic coast. The Restoration gave back to the Habsburgs both direct and indirect dominion over the Adriatic. The $19^{\text {th }}$ century was a century of modernity and of the rise of national communities (Chaline, 2001: 430-505. Above all, the eastern coast witnessed the contrast between rises of the Croatian and the Italian national feeling (Clewing, 2001). Italy's unification in fact provoked a sharp political division in the Adriatic. Beyond Italy, Austria (Austria-Hungary from 1867) and the Ottoman empire recognised in 1878 the princedom of Montenegro as a coastal state. In 1913, as a result of the Balkan wars, the Ottoman sovereignty came to an end (1479-1913) leaving place to Albania. Although the sea was a place in which the rival Italian and Austrian naval forces collided, the economic contacts between the two coasts remained very much in effect till 1945 .

In 1918 Yugoslavia succeeded Austria-Hungary and the Montenegro on the eastern bank. The tensions between this new state and Italy never ended, partly because imperialist aspirations of fascist Italy wanted to materialise in the Adriatic and the Eastern Mediterranean (Sivignon, 2001: 507-587). With the occupation of Albania in 1939 and with the occupation of the Yugoslavia in 1941, Mussolini made the Adriatic an "Italian lake" (Rodogno, 2002). That was an experiment that collapsed in September 1943, allowing the German Reich to show off in the form of the Adriatische Kustenland on this sea, and therefore in the Mediterranean.

In 1945 Yugoslavia rose again, now popular, socialist and federalist, and the Adriatic became the dividing line between Western Europe and Eastern Europe, although Tito, the Yugoslav leader, had left the Soviet block in 1948. Enver Hoxa's Albania experienced one of the most oppressive communist regimes, passing from the patronage of Moscow to the one of China, suffered the most complete isolation in comparison with the adjacent countries. The fall of 
the socialist regimes in Yugoslavia and Albania, the end of the Yugoslavian federation in 1991, opened a new phase in which the Adriatic became the boundary between the united Europe and the troubled zone of the western Balkans. The war in Europe reached again Adriatic coast in 1991 and 1995, during the Yugoslav conflicts.

A definite change came into effect only in 2004 and 2013. Beside Italy, Slovenia and Croatia entered the European Union as member-states. In 2006 the Euro-region of the Adriatic was constituted as a trans-boundary entity aimed at developing relations among regions that share waters of this sea. In a way, those trans-frontier policies, for example in the InterReg projects of the European Union, impose a new political and cultural vision of the Adriatic, a kind of regionalization of this sea ${ }^{42}$.

A common history is revealed to have a central role. The Adriatic past - the Roman heritage, the Orthodox and Byzantine heritage, the Venetian civilization, the Ottoman civilization, the Habsburg world, the age of nation-building and of national contrasts - nowadays turns into a different value, becomes a transnational heritage shared between Adriatic littorals. The transnational historical dimension is considered a tool for overcoming the "centre-suburb" logic imposed by the national political and cultural perspective, a logic that has reduced the Adriatic parts to a tourist periphery. In a different way, the sense of cross-national Adriatic belonging, a model proclaimed recently within local political environments, appears as the alternative for the future of this sea-region in order to overcome its peripherical character.

After all, the Adriatic as a boundary and in trans-boundary context constitutes a "historical object", a European historical area,

42 See: Botta, Capriati, 2003; Botta, Garzia, Guaragnella, 2007 ; Bucarelli, Monzali 2009 ; Botta, Scianatico, 2010 ; Trinchese, Caccamo, 2011; Canullo, Chiapparino, Cingolani, 2011. See also: Pécout, 2004. 
and represents in itself a transnational heritage for nations that could find their own territorial and cultural border in it $^{43}$.

\section{References}

Abulafia, D. (ed.) (2003). The Mediterranean in History. London: Thames and Hudson.

Abulafia, D. (2011). The Great Sea. A Human History of the Mediterranean. Oxford-New York: Oxford University Press.

Anselmi, S. (ed.) (1988). Italia felix. Migrazioni slave e albanesi in Occidente: Romagna, Marche, Abruzzi, secoli XIV-XVI. Urbino: Proposte e ricerche.

Anselmi, S. (1991). Adriatico. Studi di storia, secoli XIV-XIX. Ancona: Clua.

Barbero, A. (dir.) (2006-2010). Storia d'Europa e del Mediterraneo. Roma: Salerno (10 v.).

Bentley, J.H.; Bridenthal, R.; Wigen, K. (eds) (2007). Seascapes. Maritime histories, littoral cultures, and transoceanic exchanges. Honolulu (Ha.): University of Hawaii Press.

Bosetti, G. (2006). De Trieste a Dubrovnik: une ligne de fracture de l'Europe. Grenoble: Université Stendhal.

Botta, F.; Capriati, M. (eds.) (2003). Transizione nei Balcani e reti transadriatiche. Il valore della prossimità. Bari: Cacucci.

Botta, F.; Garzia, I., Guaragnella, P. (eds.) (2007). La questione adriatica e l'allargamento dell'Unione europea. Milano: FrancoAngeli.

Botta, F.; Scianatico, G. (eds.) (2010). Lezioni per l'Adriatico. Argomenti a favore di una nuova euroregione. Milano: Franco Angeli.

Braccesi, L.; Graciotti, S. (eds.) (1999). La Dalmazia e l'altra sponda: problemi di archaiologhia adriatica. Firenze: Olschki.

Branca, V.; Graciotti, S. (eds.) (1983). Barocco in Italia e nei paesi slavi del Sud. Firenze: Olschki.

Braudel, F. (1966). La Méditerranée et le monde méditeranéen à l'époque de Philippe II. 2e édition revue et augmentée. Paris: A. Colin.

Braudel, F (ed.) (1977). La Méditerranée. L'espace et l'bistoire. Paris: Arts et métiers graphiques.

Braudel, F (ed.) (1978). La Méditerranée. Les hommes et l’héritage. Paris: Arts et métiers graphiques.

Brogiolo, G.; Delogu, P. (eds.) (2005). L'Adriatico dalla tarda antichità all'età carolingia. Firenze: All'insegna del giglio.

43 See: Graciotti, 1998; Ivetic, 2014. 
Bruni, F.; Maltezou, Ch. (eds.) (2011). L'Adriatico. Incontri e separazioni (18.-19. sec.). Venezia: Istituto Veneto di Scienze Lettere ed Arti.

Bucarelli, M.; Monzali, L. (eds.) (2009). Italia e Slovenia fra passato, presente e futuro. Roma: Edizioni Studium.

Cabanes, P. (ed.) (2001). Histoire de l'Adriatique. Paris: Seuil.

Cabanes, P. (2001). "L'Adriatique dans l'Antiquité". In: Cabanes (ed.). Histoire de l'Adriatique. Paris: Seuil, pp. 23-106.

Canullo, G.; Chiapparino, F.; Cingolani, G. (eds.) (2011). The Adriatic-Balkan Area from Transition to Integration. Napoli: Edizioni scientifiche italiane.

Carpentier, J.; Lebrun, F. (eds.) (1998). Histoire de la Méditerranée. Paris: Seuil.

Cassano, F. (2011). Southern Thought and Other Essays on the Mediterranean. New York: Fordham University Press.

Cassi, G. (1915). Il mare Adriatico. Sua funzione attraverso i tempi. Milano: Hoepli.

Cetnarowicz, A. (2008). Die Nationalbewegung in Dalmatien im 19. Jabrhundert: vom 'Slawentum' zur modernen kroatischen und serbischen Nationalidee. Frankfurt am Main-New York: P. Lang.

Chaline, O. (2001). "L'Adriatique, de la guerre de Candia à la fin des Empires (1645-1918) ". In: Cabanes (ed.). Histoire de l'Adriatique. Paris: Seuil. pp. 313-505.

Chambers, I. (2008). Mediterranean crossings. The politics of an interrupted modernity. Durham: Duke University Press.

Clewing, K. (2001). Staatlichkeit und nationale Identitätsbildung. Dalmatien in Vormärz und Revolution. München: Oldenbourg.

Cocco, E.; Minardi, E. (eds.) (2007). Immaginare l'Adriatico. Contributi alla riscoperta sociale di uno spazio di frontiera. Milano: FrancoAngeli.

Corbin A.; Richard, H. (eds.) (2004). La mer, terreur et fascination. Paris: Bibliothèque nationale de France-Seuil.

Di Vittorio, A. (ed.) (1981). Sale e saline nell'Adriatico, secoli XV-XX. Napoli: Giannini.

Doumerc, B. (2001). "L'Adriatique du XIII ${ }^{\mathrm{e}}$ au XVII ${ }^{\mathrm{e}}$ siècle". In : Cabanes (ed.). Histoire de l'Adriatique. Paris: Seuil, pp. 201-305.

Ducellier, A. (2001). "L'Adriatique du IV $\mathrm{e}^{\mathrm{e}}$ au XIII $\mathrm{e}$ siècle". In: Cabanes, P. (ed.). Histoire de l'Adriatique. Paris: Seuil, pp. 107-200.

Falaschini N.; Graciotti S.; Sconocchia S. (eds.) (1998). Homo Adriaticus: identità culturale e autocoscienza attraverso i secoli. Reggio Emilia: Diabasis.

Fiori, F. (2005). Un mare. Orizzonte adriatico. Reggio Emilia: Diabasis.

Frascani, P. (2008). Il mare. Bologna: il Mulino (L'identità italiana).

Graciotti S. (ed.) (1992). Il libro nel bacino adriatico, secoli XV-XVIII. Firenze: Olschki.

Graciotti S. (ed.) (2001). Mito e antimito di Venezia nel bacino adriatico, secoli XV-XIX. Roma: Il Calamo. 
Graciotti S. (ed.) (2009). La Dalmazia nelle relazioni di viaggiatori e pellegrini da Venezia tra Quattro e Seicento. Roma: Bardi.

Graciotti, S.; Massa, M.; Pirani, G. (eds.) (1993). Marche e Dalmazia tra umanesimo e barocco. Reggio Emilia: Diabasis.

Graciotti S. (1998). "L'homo adriaticus di ieri e quello di oggi". In: Falaschini, Graciotti, Sconocchia (eds.), Homo Adriaticus: identità culturale e autocoscienza attraverso i secoli. Reggio Emilia, Diabasis, pp. 11-26.

Harris, W.V. (2005). Rethinking the Mediterranean. Oxford-New York: Oxford University Press.

Hocquet, J.-C. (2006). Venise et la mer, XII ${ }^{e}$-XVIII ${ }^{e}$ siécle. Paris: Fayard.

Horden, P.; Purcell, N. (2000). The Corrupting Sea. A Study of Mediterranean History. Malden (Ma.)-Oxford: Blackwell.

Ivetic, E. (2011). "L'Adriatico alla fine del Settecento: il rilancio mancato". In: Bruni, Maltezou (eds). L' Adriatico. Incontri e separazioni, separazioni (18.-19. sec.).Venezia: Istituto Veneto di Scienze Lettere ed Arti, pp. 23-38.

Ivetic, E. (2011). "The Peace of Passarowitz in Venice's Balkan Policy". In: Ingrao, Ch.; Pešalj, J.; Samardžić, N. (eds.). The Peace of Passarowitz 1718. West Lafayette (In.): Purdue University Press, pp. 63-72.

Ivetic, E. (2014). Un confine nel Mediterraneo. L'Adriatico orientale tra Italia e Slavia (1300-1900). Roma: Viella.

Judde de Lariviere, C. (2008). Naviguer, commercer, gouverner. Economie maritime et pouvoirs a Venise ( $X V^{e}-X V^{e}$ siècle). Leiden-Boston: Brill.

Kayser, B. (1996). Méditerranée, une géographie de la fracture. Aix-en-Provence-Tunis-Casablanca: Edisud-Alif-Toubkal.

Klein, B., Mackenthun, G. (eds.) (2004). Sea Changes. Historicizing the Ocean. New York: Routledge.

Krekić, B. (1997). "Venezia e l'Adriatico". In: Arnaldi, G. Cracco, A. Tenenti, A. (eds.) 1997. Storia di Venezia, v. 3, La formazione dello Stato patrizio. Roma: Istituto dell'Enciclopedia italiana Treccani, pp. 43-65.

Lacoste, Y. (2006). Géopolitique de la Méditerranée. Paris: A. Colin.

Marino, J.A. (ed.) (2002). Early Modern History and the Social Sciences. Testing the limits of Braudel's Mediterranean. Kirksville (Mo): Truman State University Press.

Matvejević P. (1995). Golfo di Venezia. Venezia-Milano: Consorzio Venezia nuova-F. Motta.

Matvejević P. (1999). Mediterranean: a Cultural Landscape. Berkeley: University of California Press.

Morris, I. (2003). "Mediterraneanization". In: Mediterranean Historical Review 18/2, pp. $30-55$.

Novak, G. (1932). Naše more. Razvitak moći i plovidbe na Jadranu. Zagreb: Mjesni odbor 2. Jadranske straže u Zagrebu.

Novak, G. (1962). Jadransko more u sukobima i borbama kroz stoljeća. Beograd: Vojno delo. 
Ortalli, G., Ravegnani, G., Schreiner, P. (eds.) (2006). Quarta crociata. Venezia, Bisanzio, impero latino. Venezia: Istituto veneto di scienze, lettere ed arti (2 v.).

Ortalli, G.; Schmitt, O.J. (eds.) (2009). Balcani Occidentali, Adriatico e Venezia fra XIII e XVIII secolo-Der westliche Balkan, der Adriaraum und Venedig (13.-18. Jahrhundert). Wien: Österreichischen Akademie der Wissenschaften.

Palumbo, P.F. (ed.) (1973). Momenti e problemi della storia delle due sponde adriatiche. Atti del 1. Congresso internazionale sulle relazioni fra le sponde adriatiche (Brindisi-Lecce-Taranto, 15-18 ottobre 1971). Lecce: Centro di Studi Salentini.

Palumbo, P.F. (ed.) (1989). Per la storia delle relazioni adriatiche. Roma: Centro di studi sulla civiltà adriatica.

Pécout, G. (ed.) (2004). Penser les frontières de l'Europe du 19. au 21. siècle. Élargissement et union: approches historiques. Paris: Presses Universitaires de France.

Peron, F. ; Rieucau, J. (eds.) (1996). La maritimité aujourd'hui. Paris: L'Harmattan.

Randi, O. (1914), L'Adriatico. Studio geografico, storico e politico. Milano: Treves.

Rodogno, D. (2002). Il nuovo ordine mediterraneo. Le politiche di occupazione dell'Italia fascista (1940-1943), Torino: Bollati Boringhieri.

Sivignon, M. (2001). "Le cadre naturel". In: Cabanes, P. (ed.). Histoire de l'Adriatique Paris: Seuil, pp. 13-22.

Sivignon, M. (2001). "L'Adriatique de 1918 à nos jours". In: Cabanes, P. Histoire de l'Adriatique Paris: Seuil, pp. 507-587.

Tabak, F. (2008). The waning of the Mediterranean, 1550-1870. A geohistorical approach. Baltimore (Md.): Johns Hopkins University Press.

Tamaro, A. (1918-19). La Vénétie Julienne et la Dalmatie. Histoire de la nation italienne sur ses frontières orientales. Rome: Imprimerie du Sénat (3v.).

Trinchese, S. ; Caccamo, F. (eds.) (2011). Rotte adriatiche tra Italia, Balcani e Mediterraneo. Milano: FrancoAngeli.

Turri, E. (ed.) (1999). Adriatico mare d'Europa. La geografia e la storia, Bologna: Rolo Banca 1473.

Turri, E. (ed.) (2000). Adriatico mare d'Europa. La cultura e la storia, Bologna: Rolo Banca 1473.

Turri, E. ; Zumiani, D. (eds.) (2001). Adriatico mare d'Europa. L'economia e la storia. Bologna: Rolo Banca 1473.

Zorić, M. (1989). Italia e Slavia. Contributi sulle relazioni letterarie italo-jugoslave dall'Ariosto al D'Annunzio. Padova: Antenre. 